\title{
Sustainability/resilience of soil organic matter components in an Argentinean arid region
}

\author{
Sustentabilidad/resiliencia de los componentes de la materia orgánica del suelo en una \\ región árida de Argentina \\ Sustentabilidade/resiliência dos componentes da matéria orgânica do solo numa região \\ árida da Argentina
}

\section{AUTHORS}

\section{Vázquez C. ${ }^{1}$}

\section{Merlo C. ${ }^{1}$}

Noe L. ${ }^{1}$

\section{Romero C.}

Abril A. 1

aabril@agro.unc. edu.ar

\section{Carranza C. ${ }^{2}$}

@ Corresponding Author ${ }^{1}$ Microbiología Agrícola, Facultad de Ciencias Agropecuarias,

Universidad Nacional de Córdoba. Argentina.

${ }^{2}$ Estación Forestal Villa Dolores, INTA. Córdoba, Argentina.
Received: 22.11.2012 | Revised: 22.02.2013 | Accepted: 05.03.2013

\section{ABSTRACT}

This short communication presents a novel approach to determining the soil sustainability of productive practices in an Argentinean arid region, using the resilience degree of soil organic matter components. The study was conducted in four sites of the Arid Chaco region of the Cordoba province: one undisturbed site, two sites with livestock (with total and with selective clearing) and one site with agriculture. In each site three soil samples were taken and total soil organic matter, fulvic and humic acids, and non-humic substances were analyzed. Variations of each component (\%) between each productive practice and the undisturbed site were calculated in order to establish the resilience degree. The livestock soils showed: a) moderate resilience for non-humic substances, b) low resilience for organic matter and humic acids, and c) no resilience for fulvic acids. The agricultural soils showed: a) low resilience for total organic matter and non-humic substances, and b) no resilience for fulvic and humic acids. We conclude that this approach is a powerful tool for establishing management practices according to each particular situation, allowing improved productivity in arid regions.

\section{RESUMEN}

Se analizó el grado de resiliencia de los componentes de la materia orgánica del suelo para establecer la sustentabilidad de las prácticas productivas en una región árida de Argentina. Se trabajó en cuatro sitios en el Chaco Árido de la provincia de Córdoba: un sitio testigo, 2 sitios con ganadería (con desmonte total y selectivo) y un sitio con agricultura. En cada sitio se tomaron tres muestras de suelo y se analizó en contenido de materia orgánica total, ácido fúlvicos, ácidos húmicos y sustancias no humificadas. Se calculó la variación (\%) de cada componente entre los sitios productivos y el sitio testigo, para establecer el grado de resiliencia. En los sitios con ganadería las sustancias no humificadas fueron moderadamente resilientes, la materia orgánica total y los ácidos húmicos escasamente resilientes y los ácidos fúlvicos no resilientes. En el sitio con agricultura la materia orgánica total y las sustancias no humificadas fueron escasamente resilientes, mientras que los ácidos fúlvicos y búmicos fueron no resilientes. Se concluye que este método de evaluación de la sustentabilidad es una excelente herramienta para establecer las prácticas de manejo de acuerdo a cada situación en particular, permitiendo mejorar la productividad de las regiones áridas. 


\section{RESUMO}

O grau de resiliência dos componentes da matéria orgânica do solo foi analisado para estabelecer a sustentabilidade das práticas de produção numa região árida da Argentina. Recorreu-se a quatro locais na região árida do Chaco provincia de Córdoba: um local controlo, 2 locais com produção pecuária e um local com produção agrícola. Colheram-se três amostras de solo em cada um dos locais testados e procedeu-se à determinação dos teores de matéria orgânica total, substâncias não humificadas, e ácidas fúlvicos e huimicos. Calculou-se a variação (\%) de cada componente entre locais com produção e o controlo para estabelecer o grau deresiliência. Os locais com produção pecuária apresentaram substâncias não humificadas com resiliência moderada, matéria orgânica e ácidos húmicos com baixa resiliência e ácidos fúlvicos não resilientes. No local com produção agrícola a matéria orgânica total e as substâncias não humificadas apresentaram baixa resiliência, enquanto os ácidos húmicos e fúlvicos não apresentaram resiliência. Dos resultados obtidos conclui-se que este método de avaliação da sustentabilidade é uma excelente ferramenta para estabelecer práticas de gestão de acordo com cada situação em particular, permitindo melhorar a produtividade das regiôes áridas.

\section{Introduction}

The criteria used to defined sustainability converge on the conservation of soil organic matter (SOM) and nutrients, two factors which are dependant on soil health and quality. The magnitude of productivity impacts therefore vary with the degree of SOM resilience, where resilience is defined as the ability to return to an original condition after a disturbance (Seybold et al. 1999). Arid soils with little SOM have low resilience, and so inappropriate productivity management can lead to desertification in the short term (Feng et al. 2002).

Soil organic matter is heterogeneous and includes both humic and non-humic substances (Prentice and Webb 2010). The content of non-humic substances (NHS) is highly variable, whereas the humic substances (HS) are more resistant to biodegradation and strongly associated with soil mineral phases. Accordingly, HS are the stable SOM component (Bardy et al. 2008). The proportion between NHS and HS depends on many factors, particularly the climatic conditions and the surface residue characteristics (Abril et al. 2013). Moreover, HS include fulvic and humic acids, which differ in molecular size and functional group content: humic acids are more polymerized and aromatized than fulvic acids, and in consequence, they indicate the SOM maturity (Aranda and Oyonarte 2006).

Productive management (clearing, fertilization, tillage, irrigation, etc.) modify the amount and quality of surface residues and soil environmental conditions, changing microbial activity. These aspects affect the amount of total SOM and the HS and NHS proportion modifying the SOM resilience degree and soil sustainability. The most studies about resilience usually define degrees and thresholds based on the magnitude of variation related to an undisturbed situation, and the possibility of return to a previous condition (Lal 1997). 
For many years, land use of the dry forest of the Arid Chaco eco-region of the Cordoba province has been logging (for firewood and charcoal), and the mismanagement of livestock that led to large overgrazed areas with scarce original vegetation. Nowadays, the forest has been transformed into extensive livestock systems and high-tech irrigated agriculture, as the overgrazed forests in the region have been cleared (completely or selectively) for forage or cereal crops.

Little information is available about the sustainability level of the most common management practices in this region. This short communication presents a first research advance related to a novel approach to determining the soil sustainability, which is based on the degree of resilience of the SOM components. Our aim was to make a contribution to the planning of management practice in arid areas, which could be applied in other similar regions around the world.

\section{Material and Methods}

The study was conducted in the western arid region of the Cordoba province, Argentina $\left(31^{\circ}\right.$ $43^{\prime} \mathrm{S} ; 65^{\circ} 24^{\prime} \mathrm{W}$ ). The original vegetation corresponds to the Arid Chaco eco-region, with a predominance of xerophytic woody plants and summer grasses. The topographic and environmental conditions of the area are homogenous. The climate is warm, with high temperature summers and moderate winters $\left(24^{\circ}\right.$ and $10^{\circ} \mathrm{C}$ mean, respectively). The mean annual rainfall of $500 \mathrm{~mm}$ is concentrated in summer (NovemberMarch). Soils are sandy with neutral pH.

We selected four sampling sites with similar soil characteristics: an undisturbed site in the Chancaní Natural Forest Reserve, and three neighboring productive sites (cleared in 2004) on the Alamo farm: a) TC-livestock site: total clearing with extensive livestock (on natural grasses); b) SC-livestock site: selective clearing (30\% of tree cover) with extensive livestock (on Cenchrus cil- iaris pasture); c) TC-agriculture site: total clearing with irrigated agriculture (wheat-soybeanalfalfa-potato crop sequence).

In each site, three composite soils samples (10 sub-samples, $0-20 \mathrm{~cm}$ deep) were taken along a $500 \mathrm{~m}$ linear transect on two sampling dates: during dry season (winter 2010) and wet season (summer 2011). Soil samples were air-dried for 24 hours and stored at $4{ }^{\circ} \mathrm{C}$ until processing.

In the soil samples, we measured the total soil organic matter (SOMt) by the Walkley and Black method (Nelson and Sommers 1996), and the humic substances (HS) by alkali extraction $(\mathrm{NaOH})$. From the alkaline extract, the humic (HA) and fulvic acids (FA) were separated by acid precipitation $\left(\mathrm{H}_{2} \mathrm{SO}_{4}\right)$ following Marinari et al. (2010). Non-humic substances (NHS) were calculated as the difference between SOMt and HS (Abril et al. 2013).

We calculated the variations (\%) of each SOM component (mean values of the two sampling dates) between the productive sites and the undisturbed site. Percentages of data variation were statistically analyzed with ANOVA, using the function $\hat{y}=\arcsin \sqrt{y}$.

The resilience degrees and thresholds were established following Lal's scale (1997): a) Class 0 (variation range: $0-25 \%$ ), low degradation and high resilience soils; b) Class 1 (26-50\%), moderate degradation and moderate resilience soils; c) Class $2(51-75 \%)$, strong degradation and low resilience soils; and d) Class 3 (76$100 \%$ ), total degradation and non-resilient soils. We assumed $75 \%$ of variation as the resilience threshold. 


\section{Results}

The SOM components in the undisturbed site were: SOMt: $66.4 \mathrm{~g} \mathrm{~kg}^{-1}$; HS: $21.1 \mathrm{~g} \mathrm{~kg}^{-1}$; HA: $8.2 \mathrm{~g} \mathrm{~kg}^{-1}$; FA: $12.9 \mathrm{~g} \mathrm{~kg}^{-1}$ and NHS: $45.3 \mathrm{~g} \mathrm{~kg}^{-1}$. All analyzed SOM components in the productive sites showed significant statistical variations (negatives) compared to the undisturbed site. No parameter was included in Class 0: SOMt and NHS were included in Classes 1 and 2, while HS and HA in Classes 2 and 3 and the FA in Class 3 only (Figure 1).
The SC-livestock and TC-livestock sites presented similar degrees of resilience for NHS, HA and FA, however the SOMt and the HS from the SC-livestock site were more resilient than from the DT-livestock site. In the TC-agriculture site the soils lost more than $50 \%$ of all SOM components in relation to the undisturbed site: SOMt and $\mathrm{NHS}$ variations were included in Class 2 and FA, HS and HA variations in Class 3 , exceeding the resilience threshold (75\%) (Figure 1).

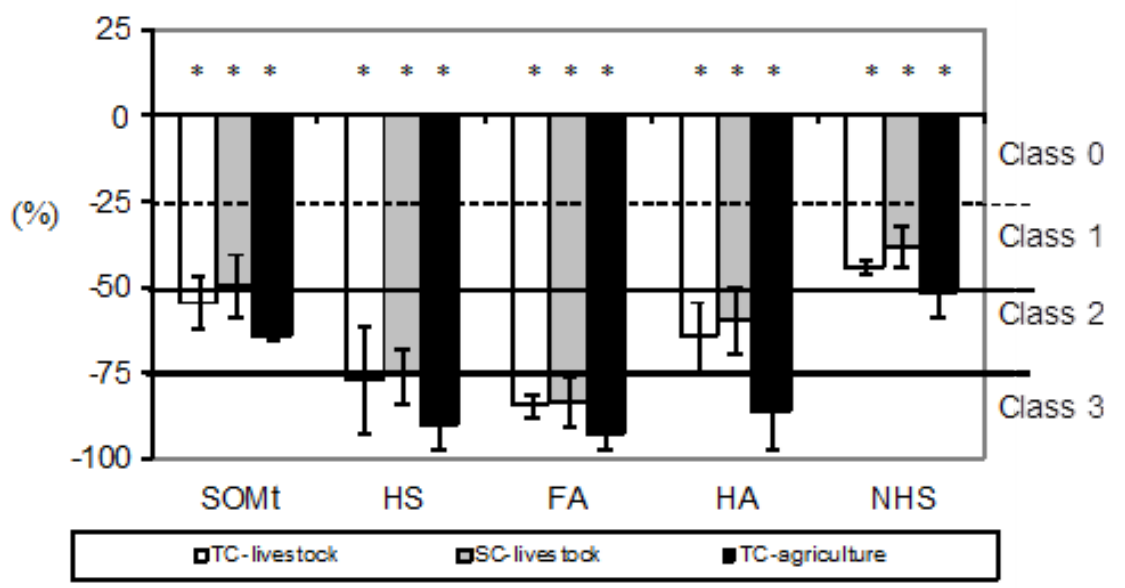

Figure 1. SOM components variation (\%) between productive sites and the undisturbed site. SOMt: total soil organic matter, HS: humic substances, FA: fulvic acids, HA: humic acids, NHS: non-humic substances. Resilience threshold: $75 \%$. *Indicates significant difference between each productive site and the undisturbed site.

\section{Discussion and Conclusions}

Our results show that all SOM components in the analyzed productive systems have undergone moderate to strong degradation in the 6 years since clearing. The loss of SOMt detected in the productive sites is in agreement with the widely accepted states for SOM in dry areas (Almendros et al. 2005; Abril and Noe 2007), however, no information is available to compare the magnitude of the SOM components losses.
The fact that NHS were less impacted in all productive sites could be due to the input of labile residues (from grasses and crops) which are not modified by the clearing. However, the humified components that depend on the woody residues are highly impacted in both the short and the long term. 
The similar resilience pattern between SC-livestock and TC-livestock sites could be due to the similar livestock management (overgrazing) and the shrub clearing practices. The high frequency of rolling work in SC-livestock affect the tree roots promoting the lost of the original tree density (Kunst et al. 2008). Note that in livestock sites, contrary to HS and FA, the HA do not exceed the threshold of resilience. This indicates that immediate restoration actions are needed in order to prevent the irreversible loss of the stable SOM. The fact that all the stable SOM components in the TC-agriculture site were included in Class 3 (total degraded sites, not resilient) indicates that agriculture in the Arid Chaco is not a sustainable practice, showing high risk of desertification (Feng et al. 2002).

From this first research advance we can conclude that the resilience degree of SOM components would be a powerful tool with which to determine management practices specific to each particular situation. This novel approach would likely also allow productivity improvement in other similar dry areas around the world.

\section{REFERENCES}

- Abril A, Noé L. 2007. Soil C sink and $\mathrm{CO}_{2}$ flux in a marginal dry forest of western Argentina. In: Verne NC, editor. Forest Ecology Research Horizons. New York: Nova Science Publishers, Inc. p. 191-202.

- Abril A, Merlo C, Noé L. 2013. Realistic soil C sink estimate in dry forests of western Argentina based on humic substance content. J Arid Environ. 91:113-118.

- Almendros G, Zancada MC, Pardo MT. 2005. Land use and soil carbon accumulation patterns in South African savanna ecosystems. Biol Fertil Soils 41:173-181.

- Aranda V, Oyonarte C. 2006. Characteristics of organic matter in soil surface horizons derived from calcareous and metamorphic rocks and different vegetation types from the Mediterranean high-mountains in SE Spain. Eur J Soil Biol. 42:247-258.

- Bardy M, Fritsch E, Derenne S, Allard T, do Nascimento NR, Bueno GT. 2008. Micromorphology and spectroscopic characteristics of organic matter in waterlogged podzols of the upper Amazon basin. Geoderma 145:222230.

- Feng Q, Endo KN, Guodong CH. 2002. Soil carbon in desertified land in relation to site characteristics. Geoderma 106:21-43.

- Kunst C, Ledesma R, Navall M. 2008. Rolado selectivo de baja intensidad. INTA, Argentina. Available from: http://inta.gob.ar/documentos/rbi-rolado-selectivo-de-baja-intensidad/

- Lal R. 1997. Degradation and resilience of soils. Phil Trans R Soc Lond B. 352:997-1010.

- Marinari S, Dell'Abate MT, Brunetti G, Dais C. 2010. Differences of stabilized organic carbon fraction and microbiological activity along Mediterranean Vertisols and Alfisols profiles. Geoderma 156:379-388.

- Nelson DW, Sommers LE. 1996. In: Sparks DL, Pages AL, Helmke PA, Loeppert RH, Soltanpour PN, Tabatabai MA, Johnston CT, Sumner ME, editors. Total carbon, organic carbon, and organic matter. Methods of Soil Analysis. Madison: Soil Science Society of America. p. 9611010.

- Prentice AJ, Webb EA. 2010. A comparison of extraction techniques on the stable carbon-isotope composition of soil humic substances. Geoderma 155:1-9.

- Seybold CA, Herrick JE, Brejda JJ. 1999. Soil resilience: A fundamental component of soil quality. Soil Sci. 164:224-234. 